\title{
Serological Specificities of Ureases of Proteus Species
}

\author{
By MELISSA M. S. GUO AND P. V. LIU \\ Department of Microbiology, University of Louisville, \\ School of Medicine, Louisville, Kentucky, U.S.A.
}

(Received 1 October 1964)

\begin{abstract}
SUMMARY
Ureases of Proteus vulgaris, $\boldsymbol{P}$. mirabilis and $\boldsymbol{P}$. rettgeri were found to be serologically indistinguishable, while that of $P$. morganii was distinct from the other three. This finding, together with recent observations on the phage susceptibilities and base ratios of the nucleic acids of these organisms, would seem to indicate that $\boldsymbol{P}$. mirabilis and $\boldsymbol{P}$. rettgeri are merely variants of $\boldsymbol{P}$. vulgaris, while $\boldsymbol{P}$. morganii is a distinct species.
\end{abstract}

\section{INTRODUCTION}

Biochemical reactions have been used in the speciation of bacteria, particularly in the field of enteric bacteriology, where the concept of a species is almost exclusively established on the basis of biochemical pattern. Evidence has accumulated which indicates that the syntheses of bacterial enzymes which carry out biochemical reactions are not always stable and the difference between positive and negative reactions in biochemical tests may not have as much significance as was once believed. For example, with tryptophan synthetases of Neurospora crassa and Escherichia coli, Yanofsky (1960) found that there were many mutants which did not synthesize this enzyme complex although the parent strains did so. Some mutants of $N$. crassa which did not produce this enzyme were able to form a protein at least immunologically related to the enzyme, whereas a second group lacked any trace of this substance (Suskind, Yanofsky \& Bonner, 1955). A similar observation has been made about lecithinase of Pseudomonas fuorescens (Bates \& Liu, 1963) and a complementation phenomenon by lecithinase-negative strains to form an active complex of the enzyme was demonstrated. This suggested that the determination of the serological specificity of an enzyme or its antigenic subunit might be a more reliable method to establish the relationship of bacterial strains than the demonstration of positive or negative reactions in biochemical tests. In this laboratory, species-specific extracellular antigens (including enzymes) have been demonstrated in the genera Pseudomonas, Aeromonas, Serratia and in other Gram-negative bacteria, and the specificities of these antigens were found useful as criteria in speciation of these organisms (Liu, $1961 a, b$; Esselmann \& Liu, 1961).

Urease production is a prominent characteristic of the genus Proteus. It has been used as a criterion in both diagnostic and systematic work to identify and differentiate Proteus from other non-lactose-fermenting pathogens. Since the classification of species within this genus is based solely upon their biochemical reactions, the relationships of the Proteus species are obscure. The present communication describes observations on the serological specificities of the ureases of Proteus species. 


\section{METHODS}

The organisms used, their sources and biochemical patterns are listed in Table 1.

Extraction and titration of urease. An organism was grown on brain heart infusion agar (Difco) containing $10 \%(\mathrm{v} / \mathrm{v})$ human blood, $2.0 \%(\mathrm{w} / \mathrm{v})$ urea and $2.5 \%(\mathrm{v} / \mathrm{v})$ glycerol at $22-25^{\circ}$ for $24 \mathrm{hr}$. The bacteria were washed off with saline, centrifuged at $14,000 \mathrm{~g}$ for $1 \mathrm{hr}$ and the supernatant fluid discarded. For Proteus morganii this process was repeated to wash the organisms, but other species were not so washed because this considerably decreased the titres of urease that was extracted.

Table 1. Sources and biochemical reaction of Proteus species used

\begin{tabular}{|c|c|c|c|c|c|c|c|c|c|}
\hline Species & Strain & Sources & $\begin{array}{l}: \\
\text { : } \\
\stackrel{8}{0} \\
\text { : }\end{array}$ & 总 & 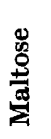 & 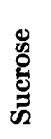 & 总 & 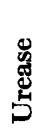 & \\
\hline P. vulgaris & $\begin{array}{l}13315 \\
4210-62 \\
1 \\
5\end{array}$ & $\begin{array}{l}\text { ATCC** } \\
\text { CDC } \dagger \\
\text { CH } \ddagger \\
\text { CH }\end{array}$ & $\begin{array}{l}\text { AG } \\
\text { AG } \\
\text { A } \\
\text { AG }\end{array}$ & $\begin{array}{l}- \\
- \\
-\end{array}$ & $\begin{array}{l}+ \\
+ \\
+ \\
+\end{array}$ & $\begin{array}{l}+ \\
+ \\
+ \\
+\end{array}$ & $\begin{array}{l}- \\
- \\
-\end{array}$ & $\begin{array}{l}+ \\
+ \\
+ \\
+\end{array}$ & t \\
\hline P. mirabilis & $\begin{array}{l}402-62 \\
668-64 \\
\text { JH }\end{array}$ & $\begin{array}{l}\text { CDC } \\
\text { CDC } \\
\text { JH§ }\end{array}$ & $\begin{array}{l}\text { AG } \\
\text { AG } \\
\text { AG }\end{array}$ & $\begin{array}{l}- \\
-\end{array}$ & $\begin{array}{l}- \\
-\end{array}$ & $\begin{array}{l}\mathbf{D} \\
\mathbf{D} \\
\mathbf{D}\end{array}$ & $\bar{z}$ & $\begin{array}{l}+ \\
+ \\
+\end{array}$ & - \\
\hline P. morganii & $\begin{array}{l}6879-61 \\
252-64 \\
10\end{array}$ & $\begin{array}{l}\text { CDC } \\
\text { CDC } \\
\text { CH }\end{array}$ & $\begin{array}{l}\text { AG } \\
\text { AG } \\
\text { AG }\end{array}$ & $\begin{array}{l}- \\
-\end{array}$ & $\begin{array}{l}- \\
-\end{array}$ & - & $\begin{array}{l}- \\
-\end{array}$ & $\begin{array}{l}+ \\
+ \\
+\end{array}$ & 7 \\
\hline P. rettgeri & $\begin{array}{l}7012-61 \\
816-63 \\
13\end{array}$ & $\begin{array}{l}\text { CDC } \\
\text { CDC } \\
\text { CH }\end{array}$ & $\begin{array}{l}\text { A } \\
\text { AG } \\
\text { A }\end{array}$ & $\overline{-}$ & $\overline{-}$ & - & $\begin{array}{l}+ \\
+ \\
+\end{array}$ & + & \\
\hline
\end{tabular}

$\mathrm{AG}=$ acid with gas formation; $+=$ positive reaction; $-=$ negative reaction; $\mathrm{D}=$ delayed reaction.

* ATCC = American Type Culture Collection; $+\mathrm{CDC}=$ Communicable Disease Center, Atlanta, Ga., U.S.A.; $\quad \ddagger \mathbf{C H}=$ Children's Hospital, Louisville, Ky., U.S.A.; $\quad \S \mathbf{J H}=$ Jewish Hospital, Louisville, Ky., U.S.A.

About $10 \mathrm{~g}$ (wet weight) of organism were suspended in $50 \mathrm{ml}$. saline; $10 \mathrm{ml}$. of a solution consisting of one volume of $n$-amyl alcohol and four volumes of chloroform was added to this suspension. Effective extraction of the urease was achieved at room temperature by forcing the bacterial suspension through a narrow aperture by repeated pipetting, thus achieving thorough mixing. The mixture was then allowed to stand at $4^{\circ}$ for $24 \mathrm{hr}$. An exception was in the case of Proteus morganii, which required 2-4 days for sufficient extraction of the enzyme. The supernatant fluid (water layer) was collected by centrifugation at $14,000 \mathrm{~g}$ at $4^{\circ}$ for $1 \mathrm{hr}$.

The aqueous fluid thus obtained was sterile except in the case of Proteus morganii extracts, which had to be filtered through a sintered-glass filter to sterilize. The enzymic titre was decreased to $50 \%$ by this additional filtration. Since the ureases are very sensitive to heavy metal ions (Sumner, 1928) no preservative containing such ions, e.g. thiomersalate, was used.

Serial twofold dilutions of extract were made in saline containing $1 / 8$ dilution of normal rabbit serum which served as a stabilizer of the urease. An equal volume of urea reagent (containing \%, w/v: 2.0, urea; 0.91, $\mathrm{KH}_{2} \mathrm{PO}_{4} ; 0.95, \mathrm{Na}_{2} \mathrm{HPO}_{4} ; 0.005$, phenol red) was added and the mixture incubated at $37^{\circ}$ for $24 \mathrm{hr}$. The reciprocal of 
the highest dilution which showed a complete change of the colour of the indicator as the result of ammonia production was taken as the titre of the preparation. Two controls were used: one contained only diluent and urea reagent; the other consisted of the urease preparation and urea reagent but without urea. One unit of urease is defined here as the amount of the enzyme able to decompose urea $10 \mathrm{mg} . / \mathrm{ml}$., as shown in the aforementioned colour reaction. One unit of the jack bean urease (Nutritional Biochemical Co., Cleveland, Ohio, U.S.A.) as defined by Sumner (1926) was equivalent to 256 units in our system.

Production of antisera. For immunization, crude urease preparations of Proteus vulgaris (13315), $\boldsymbol{P}$. mirabilis (402-62, and $\mathrm{JH}$ ) and $\boldsymbol{P}$. rettgeri (7012-61) were precipitated in the cold with 3 volumes of $95 \%(\mathrm{v} / \mathrm{v})$ ethanol in water at $\mathrm{pH} \mathbf{7 \cdot 0}$, and the precipitates collected immediately by centrifugation at $1300 \mathrm{~g}$ for $10 \mathrm{~min}$. at $-10^{\circ}$. Saline containing $1 / 8$ dilution of normal rabbit serum was pre-cooled to $0^{\circ}$ and used to dissolve the precipitates to the original volume. This preparation was dialysed against phosphate buffer $\left(\mathrm{pH} \mathrm{7 \cdot 2)}\right.$ at $4^{\circ}$ for 2 days, with frequent changes of buffer.

The urease of Proteus morganii appeared to be more stable than that of the other species examined. The crude enzyme preparation was deproteinized by the addition of an equal volume of a chloroform $+n$-amyl alcohol mixture (Meyer \& Chaffee, 1941). The mixture was centrifuged at $1300 \mathrm{~g}$ at $4^{\circ}$ for $20 \mathrm{~min}$. and the aqueous phase, containing all of the urease activity, precipitated with 3 volumes of ethanol. The precipitate was dissolved in saline, $\frac{1}{4}$ of the original volume, and dialysed against phosphate buffer. The addition of serum as stabilizer was not necessary.

Samples of the extracts thus obtained $(1.0 \mathrm{ml}$.) were mixed with equal volumes of Freund's incomplete adjuvant (Arlacel and Bayol in the ratio of 1.5/8.5) and two doses were given intradermally one week apart to rabbits. These intradermal injections were usually followed by intravenous injection of the antigens without the adjuvant in 3rd and 4th weeks. However, it was found that the intraperitoneal injection of the urease + antiserum complex as described by Kirk \& Sumner (1931) gave better results. After 2 weeks the rabbits were bled and $1 \mathrm{ml}$. of the serum was mixed with an equal volume of urease preparation and injected into the same animal intraperitoneally. This injection was made twice a week during the 3rd and 4th weeks. The rabbits were bled one week after the last injection and the sera were sterilized by filtration through Millipore filters (Fig. 1). As in the case of urease preparations no preservative were used for these antisera. With this procedure antisera to the ureases of Proteus vulgaris (13315), P. morganii (6879-61) and jack

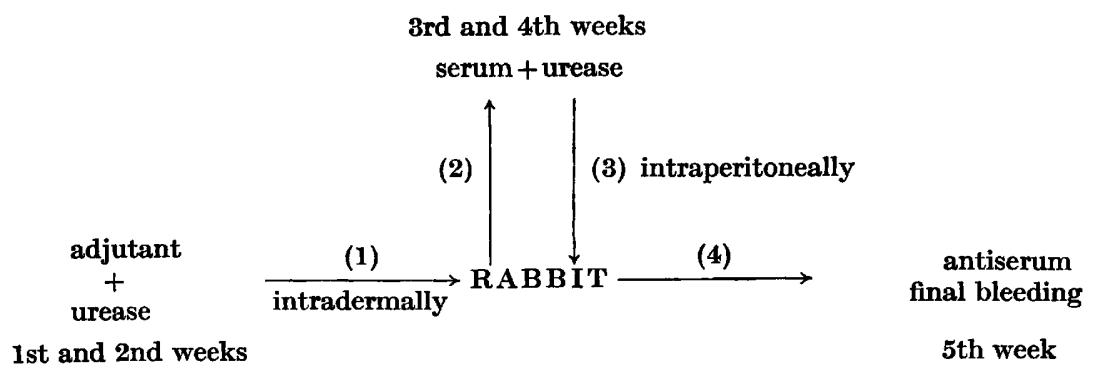

Fig. 1. The scheme for immunization of rabbits against urease. 
bean were produced. However, rabbits did not respond to the ureases of $\boldsymbol{P}$. mirabilis (402-62, JH) and $P$. rettgeri (7012-61) in spite of repeated attempts. Consequently, chickens were used. About 30 units of these ureases without rabbit serum were injected subcutaneously at weekly intervals for 5 weeks, the animals bled 8 days after the last injections.

Neutralization test. Kirk \& Sumner (1934) reported that antibody against jack bean urease precipitated the enzyme but did not inhibit its activity. A similar phenomenon was noted with ureases of Proteus species and their antisera. The activities of antisera were, therefore, estimated by the removal of urease by precipitation. A sample (0.5 ml.) of urease preparation was added to an equal volume of antiserum, incubated at $37^{\circ}$ for $1 \mathrm{hr}$, and the precipitate removed by centrifugation. The residual urease activity in the supernatant fluid was titrated in the usual way. A sample of homologous normal serum obtained from each animal before immunization was used as control. In testing the precipitating activity of chicken antisera, the antigens were prepared in $8.0 \% \mathrm{NaCl}$ solution, which was necessary for maximal precipitation in this system (Goodman, Wolfe \& Norton, 1951).

\section{RESULTS}

All attempts to prepare antisera to the urease of Proteus rettgeri were unsuccessful. In Table 2 are shown the results of cross-precipitation of five ureases and four antisera. Close immunological relationships among ureases of Proteus vulgaris, $\boldsymbol{P}$. mirabilis, and $\boldsymbol{P}$. rettgeri were evident. The only exception noted was that the urease of $P$. vulgaris (13315) was not precipitated by the antisera to the urease of $\boldsymbol{P}$. mirabilis (JH), although the urease of strain $\mathrm{JH}$ was precipitated by the antisera of strain 13315. We also examined the serological specificity of the proteases of $\boldsymbol{P}$. vulgaris and $\boldsymbol{P}$. mirabilis strains and found them to be immunologically indistinguishable. However, protease could not be used to compare these organisms with $\boldsymbol{P}$. morganii and $\boldsymbol{P}$. rettgeri because the latter two were non-proteolytic.

Table 2. Cross-precipitation of ureases and antisera of Proteus strains

\begin{tabular}{|c|c|c|c|c|c|}
\hline \multirow[b]{2}{*}{ Source of urease } & & \multicolumn{4}{|c|}{ Anti-urease serum } \\
\hline & & $\begin{array}{c}P . \text { vulgaris } \\
13315\end{array}$ & $\underset{\text { JH }}{P .}$ mirabilis & $\begin{array}{c}\text { P. morganii } \\
6879-61\end{array}$ & $\begin{array}{l}\text { Jack } \\
\text { bean }\end{array}$ \\
\hline$P$. vulgaris & $\begin{array}{l}13315 \\
4210-62 \\
\text { CH } 1 \\
\text { CH } 5\end{array}$ & $\begin{array}{c}64 / 256 * \\
4 / 16 \\
32 / 256 \\
4 / 256\end{array}$ & $\begin{array}{l}0 / 128 \\
2 / 16 \\
4 / 128 \\
2 / 64\end{array}$ & $\begin{array}{l}0 / 256 \\
0 / 16 \\
0 / 256 \\
0 / 256\end{array}$ & $\begin{array}{l}0 / 256 \\
0 / 16 \\
0 / 256 \\
0 / 256\end{array}$ \\
\hline P. mirabilis & $\begin{array}{l}668-64 \\
402-62 \\
\text { JH }\end{array}$ & $\begin{array}{l}16 / 32 \\
32 / 512 \\
32 / 512\end{array}$ & $\begin{array}{l}8 / 64 \\
4 / 64 \\
8 / 256\end{array}$ & $\begin{array}{l}0 / 32 \\
0 / 512 \\
0 / 512\end{array}$ & $\begin{array}{l}4 / 32 \\
0 / 512 \\
0 / 512\end{array}$ \\
\hline P. morganii & $\begin{array}{l}252-64 \\
6879-61 \\
\text { СН } 10\end{array}$ & $\begin{array}{l}0 / 8 \\
0 / 256 \\
0 / 64\end{array}$ & $\begin{array}{l}0 / 8 \\
0 / 64 \\
0 / 64\end{array}$ & $\begin{array}{c}8 / 8 \\
256 / 256 \\
64 / 64\end{array}$ & $\begin{array}{l}0 / 8 \\
0 / 256 \\
0 / 64\end{array}$ \\
\hline P. rettgeri & $\begin{array}{l}816-63 \\
7012-61 \\
\text { СН } 13\end{array}$ & $\begin{array}{c}8 / 64 \\
16 / 128 \\
16 / 128\end{array}$ & $\begin{array}{l}2 / 16 \\
2 / 32 \\
N D\end{array}$ & $\begin{array}{l}0 / 64 \\
0 / 128 \\
0 / 128\end{array}$ & $\begin{array}{l}0 / 64 \\
0 / 128 \\
0 / 128\end{array}$ \\
\hline Jack bean & & $0 / 512$ & $0 / 512$ & $0 / 512$ & $32 / 512$ \\
\hline
\end{tabular}

* $64 / 256=$ denominator indicates the units of urease used; numerator indicates the amount of urease removed by $0.5 \mathrm{ml}$. antisera. 
The ureases of all three strains of Proteus morganii were immunologically indistinguishable and were distinct from those of other species. No cross-reaction was noted between jack bean urease and Proteus urease, with only one exception. The urease of $\boldsymbol{P}$. mirabilis (668-64) was invariably precipitated by antiserum to jack bean urease, although the extent of precipitation was much less than that with the homologous urease.

\section{DISCUSSION}

A close relationship of Proteus vulgaris and $\boldsymbol{P}$. mirabilis has been recognized since the work of Wenner \& Rettger (1919). The present classification of four species within the genus Proteus was the result of a study by Rustigian \& Stuart (1945). However, there was disagreement even between these two authors: Rustigian was inclined to give specific rank to $\boldsymbol{P}$. mirabilis while Stuart was inclined to group the two 'types' into one species, $\boldsymbol{P}$. vulgaris. Production of indole has been considered to be of some taxonomic significance and on this basis Rustigian \& Stuart (1945) separated $\boldsymbol{P}$. mirabilis from $\boldsymbol{P}$. vulgaris as distinct species. However, recent studies on the tryptophan synthetase of Escherichia coli (Yanofsky, 1960) indicated that the indole production is subject to the same degree of variations as any enzyme system within the descendants of a single strain. Demonstration of the serological relationship of their ureases would support the concept that these two organisms are closely related (only variants of one species).

Proteus rettgeri is generally considered to be quite distinct from other species of the genus Proteus because of its ability to ferment mannitol and its failure to liquefy gelatin (Rustigian \& Stuart, 1945); recent evidence, however, suggested that this organism might be closely related to $P$. vulgaris and $P$. mirabilis. Vieu (1958) reported the isolation of bacteriophages which lysed $\boldsymbol{P}$. vulgaris and $\boldsymbol{P}$. mirabilis as well as $P$. rettgeri but not $P$. morganii. Falkow, Ryman \& Washington (1962) reported that the base composition of the deoxyribonucleic acids (DNA) of $P$. rettgeri, as expressed in terms of guanine + cytosine $(\mathbf{G}+\mathbf{C})$ content, was exactly the same as those of $\boldsymbol{P}$. vulgaris and $\boldsymbol{P}$. mirabilis, while that of $\boldsymbol{P}$. morganii was distinct. The authors did not consider the similarity of $\mathrm{G}+\mathrm{C}$ content alone as sufficient evidence to indicate that two organisms belong to the same species, because many widely different organisms can possess DNAs of similar base content. However, demonstration of the serological relationship of the urease of $\boldsymbol{P}$. rettgeri with those of $\boldsymbol{P}$. vulgaris and $\boldsymbol{P}$. mirabilis would indicate that the structures of the genes that direct the synthesis of this enzyme in these three organisms are very similar because, if one accepts the one gene-one enzyme hypothesis, the amino acid sequence of each enzyme is a direct translation of the nucleotide sequence in a segment of the genetic material. It appeared to be more reasonable, therefore, to consider $\boldsymbol{P}$. rettgeri as a non-proteolytic and mannitol-fermenting variant of $\boldsymbol{P}$. vulgaris.

Proteus morganii has characteristics which are quite different from those of $\boldsymbol{P}$. vulgaris and $\boldsymbol{P}$. mirabilis; it resembles Salmonella in many respects (Morgan, 1906). $P$. morganii was later transferred to the genus Proteus because of its urease reaction. The study of Falkow et al. (1962) indicated that the $\mathrm{G}+\mathrm{C}$ ratio of the DNA of $P$. morganii was similar to those of the Escherichia-Shigella-Salmonella group, and not with those of $\boldsymbol{P}$. vulgaris or $\boldsymbol{P}$. mirabilis. The serological nonidentity of the urease of $\boldsymbol{P}$. morganii with the ureases of the $\boldsymbol{P}$. vulgaris group 
is evidence that this species is distinct from the other Proteus species. Whether $\boldsymbol{P}$. morganii is actually closely related to Shigella-Salmonella group remains to be proven. If it could be shown, however, that the enzymes of $P$. morganii are indistinguishable serologically from those of other enteric bacilli it would then be more reasonable to consider this organism as a urease-positive variant of these enteric bacilli. In this case, only one species of Proteus, namely $\boldsymbol{P}$. vulgaris, should be recognized with $\boldsymbol{P}$. mirabilis and $\boldsymbol{P}$. rettgeri as synonyms.

This paper is based on portions of a dissertation submitted by Melissa M. S. Guo in the University of Louisville, in partial fulfilment of the requirements for the Master of Science degree.

The work was supported by an U.S. Public Health Service research career development award (GM-K3-15) received by P. V. Liu.

\section{REFERENCES}

Bates, J. L. \& Lru, P. V. (1963). Complementation of lecithinase activities by closely related pseudomonads; its taxonomic implication. J. Bact. 86, 585.

EsselmanN, M. T. \& Liv, P. V. (1961). Lecithinase production by gram-negative bacteria. J. Bact. 81, 939.

Falkow, S., Ryman, I. R. \& Washington, O. (1962). Deoxyribonucleic acid base composition of Proteus and Providence organisms. J. Bact. 83, 1318.

Goodman, M., Wolfe, H. R. \& Norton, S. (1951). Precipitin production in chickens. IV. The effect of varying concentrations of $\mathrm{NaCl}$ on precipitate formation. J. Immun. 66, 225.

Kirk, J. S. \& Sumner, J. B. (1931). Antiurease. J. biol. Chem. 94, 21.

KIrK, J. S. \& Sumner, J. B. (1934). The reaction between crystalline urease and antiurease. J. Immun. 26, 495.

Lrv, P. V. (1961 a). Identification of pathogenic pseudomonads by extracellular antigens. J. Bact. 81, 28.

LIU, P. V. (1961 b). Observations on the specificities of extracellular antigens of the genera Aeromonas and Serratia. J. gen. Microbiol. 24, 145.

Meyer, K. \& Chaffee, E. (1941). The mucopolysaccharides of skin. J. biol. Chem. 138, 491.

MoRgan, H. DER. (1906). Upon the bacteriology of the summer diarrhoea in infants. Brit. med. J. 1, 908.

Rustigian, R. \& Stuart, C. A. (1945). Biochemical and serological relationships of organisms of genus Proteus. J. Bact. 49, 419.

Sumner, J. B. (1926). The isolation and crystallization of the enzyme urease. J. biol. Chem. 69, 485.

Sumner, J. B. (1928). Crystalline urease. II. J. biol. Chem. 76, 149.

Suskind, S. R., Yanofsky, C. \& Bonner, D. M. (1955). Allelic strains of Neurospora lacking tryptophan synthetase; a preliminary immunochemical characterization. Proc. natn. Acad. Sci., U.S.A. 41, 577.

VIEU, J. F. (1958). Note préliminaire sur la lysotypie de Proteus hauseri. Z. Bakt. I. Abt. Orig., 171, 612.

Wenner, J. J. \& RetTger, L. F. (1919). A systematic study of the Proteus group of bacteria. J. Bact. 4, 331.

YANOFSky, C. (1960). The tryptophan synthetase system. Bact. Rev. 24, 221. 